JOURNAL OF SECURITY AND SUSTAINABILITY ISSUES

ISSN 2029-7017 print/ISSN 2029-7025 online

2019 December Volume 9 Number 2

http://doi.org/10.9770/jssi.2019.9.2(13)

Scopus

\title{
INSIGHTS INTO THE EXTERNAL DEBT, CORRUPTION AND ECONOMIC GROWTH NEXUS: A CASE STUDY
}

\author{
Sakapas Saengchai ${ }^{1}$, Chanathat Boonrattanakittibhumi², Buppachart Urairak ${ }^{3}$ \\ ${ }^{1}$ Faculty of Humanities and Social Sciences, Suan Sunandha Rajabhat University, Bangkok, Thailand \\ ${ }^{2}$ Business and Administration Department, King Moungkult's Institute of Technology, \\ Prince of Chumphon Campus, Chumphon, Thailand \\ ${ }^{3}$ MBA Program in Industrial Management, Ramkhamhaeng University, Bangkok, Thailand

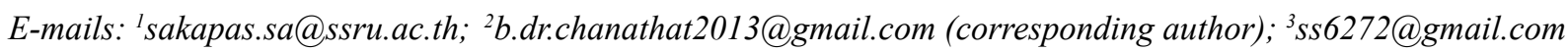

Received 25 January 2019; accepted 23 September 2019; published 30 December 2019

\begin{abstract}
This study basically examines the relationship between government external debt, corruption, and ECNG in selected five ASEAN countries, by estimating the magnitude and direction of the regression relationship, as well as the causal relationship. In addition, as a contribution in the direction of government and economic policymakers, this study intends to proffer recommendations as to the efficient management of public resources, in order to cushion the adverse effects of external indebtedness on other macroeconomic variables and welfare standards. Such effects include high cost of servicing, corruption, and capital flight, considering that investors fear being highly taxed when debts get to a certain level by the government. The findings of the study have revealed the fact that the the negative results on the economy, there is need for addressing the threat of increasing debt by the government through using alternative sources of capital investment. This can include economy openness for capital and relaxing the import restrictions and increased valuable exports. Investment can be increased in the domestic economy and wealth can be created through realizing the in-tax revenue from capital imported, which is against the interest payment on external debt. Moreover, the investment can increase ECNG, which results in transfer of technology to the domestic economy increasing the probability of more employment opportunities.
\end{abstract}

Keywords: external debt; corruption

Reference to this paper should be made as follows: Saengchai, S., Boonrattanakittibhumi, C., Urairak, B. 2019. Insights into the external debt, corruption and economic growth nexus: a case study, Journal of Security and Sustainability Issues 9(2): 533-546.

http://doi.org/10.9770/jssi.2019.9.2(13)

JEL Classifications: H6, D73

\section{Background}

The aspiration of every economy is to translate the periodical growth to development, since the growth of an economy is a sine-qua-non for economic development (Mikail \& Zainol 2018; Haseeb, Kot, Hussain, \& Jermsittiparsert, 2019; Kasayanond, Umam, \& Jermsittiparsert, 2019; Zeibote et al., 2019; Prakash, Garg, 2019; Baltgailis 2019). In the quest for this development through stable growth in economic activities, a country usually supplements domestic resources with external finances. This may be in the form of loans, grants, and remittance; among others. Besides, the burdens of heavy debts, corruption, and declining growth have gone a long way in undermining economic recovery and stabilization efforts, alongside their devastating effects on ASEAN economy, being the continent with the highest debts and highest dependence on aid/grants in the world. Similarly, the experience of debt in the ASEAN countries in particular, and Asia in general has revealed that human and physical capital is being used on debt servicing. The supposed efforts of the Bretton-Woods Institutions (IMF \& World Bank) to cushion the effects of debts on debtor nations have largely compounded the amount and burden of debts; and the debt-rescheduling initiatives of these institutions have also enhanced more debts 
in attempts to repay old loans; thus debts are being used for debts and interests on these debts keep compounding. In fact, despite the years of various policy initiatives, the market and economic changes instigated by these institutions have not resulted in any tangible improvement in welfare standard and poverty reduction. Part of the reasons for the continued rise in external debts in the ASEAN (and Asia) countries has been the failure of IMF, World Bank and other creditor agencies to consider both the economic and non-economic environments of these countries while advancing loans to them. Such environments include, among others, the exchange rates devaluation, political unrest, and the volatility of primary commodity prices, which are part of the major challenges in the ASEAN countries, as evident from their continued increase in external indebtedness and slowing economic growth (ECNG).

The level of corruption and resources mismanagement, which is a common characteristic in the ASEAN countries, has gone a long way in weakening virtually all economic institutions, including social and political institutions; with the resultant effect of undermining equity, fairness, efficiency and transparency, thereby preventing the emergence of well-performing government and social structures (Jermsittiparsert, Sriyakul, \& Pamornmast, 2012; Malik \& Khan 2013; Jermsittiparsert, Sriyakul, \& Rodoonsong, 2013). In most of these countries, these rent-seeking activities have almost become a daily routine, commonplace, and are such institutionalized that they have been tagged these countries' second nature. Here it has to be noted that similar issues are characteristic and for other countries (e.g. Luzgina, A. 2017; Osipov et al. 2018).

There is no doubt in the fact that a moderate and well productive level of debt is desirable for sustained ECNG. In fact, the issue of debts might not have been such debatable in the concerned countries if there had been experiences of their proper channel into productive economic activities (given that effective debt management is essential for ECNG). However, as part of the effects of resources mismanagement which has become pronounced in the ASEAN countries, attempts to obtain loans have been largely opposed by citizens and activists, and its adverse effects have been largely felt. This occurs alongside the severe deficits in current accounts balances, in addition to low level of savings and declining balance of payments, rising public spending, as well as increased prices of imports (being countries that largely depend on imported products and services). All these factors, among others, result in increased external debt (Buthelezi \& Nyatanga, 2018; Mabika, 2016; Korkmaz, 2015) as cited in Abdullahi, Hassan, and Bakar (2016). Alternatively, even as investment in infrastructure and public capital largely promotes ECNG, lack of adequate savings, and borrowing in anticipation of revenues may expose the economy.

This study basically examines the relationship between government external debt, corruption, and ECNG in selected five ASEAN countries, by estimating the magnitude and direction of the regression relationship, as well as the causal relationship. In addition, as a contribution in the direction of government and economic policymakers, this study intends to proffer recommendations as to the efficient management of public resources, in order to cushion the adverse effects of external indebtedness on other macroeconomic variables and welfare standards. Such effects include high cost of servicing, corruption, and capital flight, considering that investors fear being highly taxed when debts get to a certain level by the government.

\section{Literature Review}

\subsection{External Debt and ECNG}

Many researchers hold on to the view that a high level of debt has adverse effects on ECNG (Megersa, 2015; Loukil, 2017; Whajah, Bokpin, \& Kuttu, 2019), even as the ECNG theorists support the borrowing by poor countries in a bid to complement domestic resources and finance growth and development (Manaf \& Ibrahim 2017; Popov, 2018). The attainment of the target growth rate requires foreign assistance, especially in developing and ASEAN countries where the level of domestic savings and investment are relatively low. The theory regards external finance as a way by which any development gap could be filled in order to achieve the target growth rate of the economy. 
In the areas of external finance, including external indebtedness, there have been large claims that assistance from the donor countries dispatched to the low-income countries likely follows the formers' political and strategic importance, and not based on the needs of the countries. Mustafa, Elshakh, and Mustafa (2018) claims that foreign assistance has some distorting outcomes on the recipient countries' political system; and leads these economies into making inappropriate economic policies, such as the limit on the inflow of private capital, enhancement of rent-seeking activities, as well as pricing systems that tend to retard the growth of other primary sectors (such as agriculture). According to Çiftçioğlu and Sokhanvar (2018), the requirement for debt service has a tendency to reduce available funds for investment and therefore hindering the attainment of the target growth rate.

In the works of Kaur (2019), the vulnerability of debt service in developing countries is explained by the size of external loans, which has been much larger than equity finance, thereby resulting in debt-equity imbalance; the ratio of debts at floating interest rates which has risen dramatically to the extent that borrowers are directly affected upon the rise in interest rates; and the fact that the maturities of debts have largely shortened as a result of declining share of official flows. As argued by S. W. Olawale (2017), the effective management of debt management is important in an increasingly complex financial environment. Therefore, he contends that the crucial elements of debt management are the effective regulatory environment, policy co-ordination, as well as a system of accountability. Similarly, the level of debts that is development driven largely relies on the adoption and implementation of fiscal adjustment and structural reforms by the borrowing countries. These include, among others, the stemming of corruption, transparency and high level of accountability in public service, as well as improved debt management structures.

The increase in the burden of debt service beyond capacity, occasioned by expansion in external debt, requires that the situation be substituted through expansion in exports; unless increased borrowings will be required for debt servicing, while external debt keeps increasing beyond sustainable threshold. The inability of the country to realize the required revenue neceAseanry to meet the repayments obligations further compound the debt problem (Marshal, 2017; Mahmud, 2018). This is supported by Stone (2019), who is of the view that the adverse effect of both external and domestic debts on ECNG is through their likelihood of compounding an economy's debt stock and interest payments, with the resultant effect of crowding-out both public and private investment, alongside its adverse effect on domestic currency occasioned by the inflow of foreign currency through external debt.

By observing the ECNG and external debt relationship, it is expected that effective utilization of debts will increase the amount of government capital that can be invested in infrastructure, thereby resulting in the increase of domestic economic activities and investments. Contrarily, the past experiences of third-world economies have shown that large part of external and domestic debts were used for the basic infrastructure development, in order to improve growth and to attract investment and have not been utilized for the judicious purposes. Eberhardt and Presbitero (2015) conducted a research for analyzing long-run growth and public debt, by using a data for 118 economies, for a period of 1961-2012. These countries include 36 high-income economies, 33 upper-middle income economies, 27 lower middle-income economies, and 22 low-income economies and employed standard non-linear (expressing non-linearity by including a square of a debt stock term) and linear regression models, and common correlated effect (CCE) and common correlated effect mean group (CMG) as the statistical techniques for estimation. The results indicated a significant positive long-run relationship among GDP and debts, whereas, for each estimation technique, significant but negative error correction terms were obtained having values of less than one. These findings are consistent with Siddique, Selvanathan, and Selvanathan (2015). For the short term relationship, mean group estimator was used and reported a significant negative coefficient of debt, indicating that there exists a negative relationship among GDP and debt.

However, Megersa (2015) and Chiu and Lee (2017) have reported positive value for the debt coefficient. Thus, in order to analyze the debt-growth relationship and Laffer curve for 22-low income ASEAN economies, for the years 1990-2011, Megersa (2015) employed a pooled OLS estimation method and concluded that debt significantly affect ECNG and has positive impact up to a certain point. In another study, Olawale and Has- 
san (2016) have pointed out positive relationship of GDP with external debt and interest on external debt, and also suggested that up to a certain point external debt positively contributes to the GDP, and after that level it starts to negatively contribute to the GDP, through its non-linear effect. Furthermore, another study Chiu and Lee (2017) examined how ECNG in Six Pacific Island economies is affected with external debt, during 19882004, and reported that higher debts stimulate ECNG (Chitra et al., 2018; David et al., 2018). This study also observed that the short run causal relationship exists from external debt to ECNG. In a similar vein, the external debt-growth linkage in Malaysia is analyzed by S. W. Olawale (2017), by using an autoregressive distributed lag model (ARDL) for the years, 1991Q1-2009Q4. The study reported that external debt accumulation is found to be positively related to the optimum ECNG level in Malaysia, however, any further increase in external debt above this level would result in its inverse contribution to the Malaysian ECNG. The results indicated a positive and a negative coefficient of interest on the Malaysian external debt.

Contrarily, the results obtained for the static non-linear and linear models, using CMG and MG estimators have shown a significant negative relation among debt coefficient and GDP (Eberhardt \& Presbitero, 2015; Lari, NYangweso \& Rono 2017), which is consistent with the Megersa (2015) findings, who also found negative coefficients for both estimated debt and debt square. Furthermore, in a study to estimate the non-linear and linear effects of external debt on the Nigeria's ECNG, for the period 1975-2005, Olawale and Hassan (2016) used generalized least square (GLS) and Ordinary least squares (OLS) techniques. They found that interest on external debt and external debt are significantly as well as negatively related to ECNG. Similar findings were obtained in their study, they attempted to examine the effects of government and debt size on the country's ECNG. For this purpose, they incorporated the data for 175 economies during 1997-2008, and used traditional fixed and random effects models for the statistical estimation.

Researcher also conducted a research by taking a sample of heavily-indebted poor countries (HIPCs), for the time period 1970-2007, using Mean group (MG), dynamic fixed effect (DFE) and pooled mean group (PMG) techniques for the empirical estimation. The results indicated significant negative coefficients, both in short and long-run for external debt in terms of ECNG. Abdullahi et al. (2016) also found significant negative short run and long run relationship of each external debt service and external debt coefficient for capital formation, at 5\% level of significance. This study used the data for 1980-2013 by using an ARDL approach to assess the ECNG and external debt relationship, taking capital formation as the dependent variable. Similarly, Senadza, Fiagbe, and Quartey (2017) also studied the case of 35 ASEAN economies in order to assess that how external debt has affected the ECNG of these countries during 1980-1990, by employing OLS estimation technique. He concluded that ECNG is found to be negatively influenced by net outstanding debt, therefore, it signifies that level of investment and external debt are negatively correlated with each other.

\subsection{Corruption and ECNG}

Some economic researchers, such as Huang (2016) and Mbaku (2019) have argued in favor of corruption as an enhancing factor of economic exchange, as they claim it helps to overcome some cumbersome regulations. This, in their arguments, explains that corruption positively influences ECNG as the productivity of labor is assumed to rise with illegal incentives to economic agents in order to speed up their activities. In addition, they suggested that corporations or individuals may involve in bribing the policy makers to avoid unfavorable circumstances that are either created due to political inflexibilities or by the regulations and laws imposed by law enforcement agencies, which result in the improvement of economic efficiency. A few researchers have argued that an optimum corruption level exists while an economy tends to achieve national output maximization (Huang, 2016; Khan, 2018). Even if the corruption level is relatively low, the anti-corruption efforts also involve some cost. Several economies achieve rapid ECNG even in the existence of corruption. This is in contrast to Bardhan (2018) view, who argued that corruption is likely to have a negative impact on growth, however, his view has been based upon historical experience instead of modern empirical research. In a similar scholar also reported adverse effects of corruption on growth, these effects include discouraging FDI, reduction in domestic investment, distortions in the composition of government expenses, and promoting government overspending. This is in consistent with Ivanyna, Moumouras, and Rangazas (2016) statement that corruption majorly affect growth by causing its effects on investment. 
Huang (2016) also examined the whether corruption cause negative effects on ECNG, by using panel data for 13 Asian-Pacific economies during 1997-2013, and employed a Granger causality approach for assessing heterogeneity and cross-sectional dependence across countries. The study found significant positive causality for South Korea i.e. from corruption to ECNG, and significant positive causality for China i.e. from ECNG to corruption. In this study, the researcher did not reinforce the idea that corruption is harmful for the ECNG, rather supported the idea of 'grease the wheels' for the corruption-ECNG relationship in South Korea, because the anti-corruption policies of the government may seem to be ineffective in promoting economic development. The study also suggested that the increase in ECNG is found to promote the level of corruption in China. In a study by Coupet (2018), a significant positive association is found among ECNG and corruption in OECD countries, during 1960-1989, using an OLS estimation technique. According to Coupet this positive relationship may be obtained because opportunity cost is involved in eradicating corruption, for instance, when a developing economy use its existing resources towards the detection as well as for the prevention of corruption activities, the relationship comes out to be positive, but with the diminishing returns.

These findings do not coincide with the Lazreg and Mohammed (2019) study on economic development and corruption, in which Two-stage least square and OLS techniques were employed for analyzing the empirical evidence of their linkage, during 1970-1995. It is obtained that one unit increase in corruption lowers the productivity by $2-4 \%$ of GDP, and $0.5 \%$ of GDP decline in net annual capital inflows. In another study, Kaplan and Akçoraoğlu (2017) observed 41 empirical researches including 460 estimates, with an attempt to analyze how corruption influence growth and concluded that even if the trade openness and institutions are considered or not, using fixed effects and authors affiliation may tend to minimize corruption's negative effects on the ECNG but not completely eliminate these effects. Similarly, Gründler and Potrafke (2019) also attempted to observe direct effects caused by corruption on ECNG, by examining 327 estimates from 29 primary researches. The study reported heterogeneous findings due to difference in sample periods, country coverage, and difference in measures used for corruption, and estimation techniques, thus obtained negative impact in primary studies. In case of non-OECD and non-oil countries, author found that corruption negates the welfare standard of a society through its influence on the level of investment and ECNG, since significant negative association is obtained for ECNG and corruption. Also a significant negative association is found between the square of corruption and ECNG, which implies that a significant negative non-linear association exists among output per worker and corruption in OECD countries. These results are obtained by employing non-linear and linear OLS estimation. Lambsdorff (2015) study results can be used for assessing that what effects control of corruption may have on external debt and ECNG. The control of corruption is taken as the 'absence of corruption', thus, for all countries such as non-oil, non-OECD, and OECD countries, a significant positive relationship is obtained for average net annual capital inflows (to the GDP ratio) and absence of corruption, during 1970-1995, by employing TSLS and OLS techniques for estimation. With TSLS technique, the coefficient for government stability with respect to net annual capital inflows is also found to be the same. Thereby implying that popular support for government, higher government unity and strong legislative power are highly critical for achieving productivity and ECNG.

\subsection{Hollis Chenery's Two-Gap Theory}

Chenery and Strout (1966) have put forward, the two-gap approach to economic development. The basic idea is that foreign exchange and savings gaps are two separate and independent constraints to attaining the target growth rate in less developed countries (LDCs). Thus, they see external finance as a way by which these two gaps may be filled in order to achieve the target growth rate of the economy. Specifically, the authors identified that to achieve the target growth rate, an economy is required to supplement domestic resources with external finance, which may be in the forms of grants, remittance or debt.

This model is an extension of the popular Domar (1946), and Harrod (1939) model, down from Keynes (1929) the Neo-classical model. The pre-conditions for ECNG were identified such that the Savings Gap arises when the domestic savings isless than the investment required to achieve the target growth rate. For instance, if the growth target of national real income is 6 percent, and the capital-output ratio is $3: 1$, then the economy must save 18 percent of its national income to achieve this growth rate. On the other hand, inadequate foreign ex- 
change, which may arise from lower export values relative to import values, results in fall in the stock of foreign exchange. This is known as the Foreign Exchange Gap. Offsetting these two gaps, therefore, requires the inflow of foreign aids, which may be in the form of grants, remittances, loans and/or any other form of foreign debts or assistance (Bruno \& Chenery, 1962). Hence, such external finance supplements the available domestic resources and brings the two-gap model into play. The model assumes that developing economies are likely to face foreign exchange constraints or are short of domestic savings. this model assumes that the nature of foreign-exchange gap and savings gap independent and are different in magnitude, which implies that at any point one of these gaps are dominant than the other, for any developed economy (Todaro \& Smith, 2004). Assuming a fundamental macroeconomic identity in which the aggregate output equals the aggregate expenditure $(\mathrm{Y}=\mathrm{AE})$, such that $\mathrm{Y}=\mathrm{C}+\mathrm{I}+(\mathrm{X}-\mathrm{M})$, where: $\mathrm{Y}=$ national income; $\mathrm{C}=$ consumption; $\mathrm{I}=$ investment (or domestic capital formation); $\mathrm{X}=$ exports; and $\mathrm{M}=$ imports. By subtracting $\mathrm{C}$ from both sides, the resulting equation is: $\mathrm{Y}-\mathrm{C}=\mathrm{I}+(\mathrm{X}-\mathrm{M})$; where $(\mathrm{Y}-\mathrm{C})=\mathrm{S}$ (domestic savings). Thus, these two constitute the two separate constraints, and the elimination of one does not get rid of the other.

Since it is assumed that domestic investment can be financed through domestic savings and through the inflows of capital $(F)$, where $F=M-X$, the equation may be presented as $F=I-S$ (or $I=F+S$ ). However, too small savings lower than the level acceptable for the country to make investment, may create a savings gap. Similarly, too small exports for permitting the required level of imports to ensure efficient resource usage in the economy may also create a foreign exchange gap. The two-gap theory is adopted based on its relative importance in the analysis of capital flow. It useful for estimating the less-developed country's capital requirement for growth; in terms of how much capital can be generated within the economy and the requirement through foreign sources, so as to achieve the target growth rate. In addition, it aids proper understanding of the extent to which foreign resources are required to fill the savings gap and foreign exchange gap in order to attain sustainable development. Also, the divergence between the two gaps highlights the role of external finance in economic development. If the savings gap exceeds the foreign exchange gap, it may be narrowed by the inflow of capital; and the foreign exchange gap between investment and savings will be bridged in the long-run, hence the two-gap model comes into play. Alternatively, if the foreign exchange gap exceeds the savings gap, external finance results in increased investment and, therefore, ECNG.

The Augemnted Solow Growth model (1956) was adopted from Coupet Jr (2003) study, to investigate the corruption-economic growth relationship. Coupet Jr (2003) transformed this model to assess the corruption's impact on a country's level of productivity. Therefore, presuming an economy with particular focus on producing a single commodity using a Neo-classical production function.

$$
A G R I_{t}=K_{t}^{\alpha} K_{t}^{\beta}\left[L M P_{t}(\varphi) L a b_{t}\right]^{1-\alpha-\beta}
$$

where: where $A G R I_{t}$ is the aggregate of the real income, $K_{t}^{a}$ represents physical capital, $H t$ is the level of human capital, $L a b_{t}$ is labor employed, $L M P_{t}$ is basically a multifactor of country's productivity and $\rho$ is the level of corruption in a country; such that $L M P_{t}(\varphi)<0$.

Supposing that $0<\alpha<1,0<\beta<1$ and $\alpha+\beta<1$, the production function is assumed to exhibit a positive, yet diminishing marginal returns to labour and capital; [2]

$$
\frac{d K}{d t}=S_{K} A G R I_{t}-\varphi_{K} K_{t}
$$

and

$$
\frac{d H}{d t}=S_{H} A G R I_{t}-\varphi_{H} K_{t} \ldots
$$

Where, S_K, S_H, $\varphi_{-} \mathrm{K}$ and $\varphi_{-} H$ represent a set of exogenous parameters, indicating the allocation of income share in physical investment, human capital investment, and physical and human capital's depreciation rates, 
respectively. The total population is assumed to be determined exogenously and represented as Lab_t $=$ Lab_0 $\mathrm{e}^{\wedge} \mathrm{nt}=$ Loent keeping the population growth rate constant, during a specified period of time, $\mathrm{i}$ e $(\underline{\mathrm{dI}} \mathrm{ah} / \mathrm{dt}) / \mathrm{Labt}=\mathrm{n} 2$. Furthermore, when, At shows the multifactor productivity of an economy, $L M P_{t}(\varphi)=L M P_{t} e^{-\vartheta \varphi}$. The corruption variable is added into the model, assuming it to be exogenous which may decline productivity of inputs, by taking the form of externalities effect in declining inputs quality. Firms which involve in bribery to evade fines, not only impose negative externalities upon other firms but also lead to the reduction in their level of investment. For instance, in an attempt of producing public goods through starting a new venture by a higher government official with an unqualified cronies, would result in the reduction of private sector productivity (Tanzi \& Davoodi, 1998). Thus, $\varphi$ and $\vartheta$ represents the corruption parameters which jointly have their effects on the productivity of multiple factors. Moreover, $\rho$ measures the overall corruption level in the economy and $\vartheta$ measures the corruption's responsiveness to production function.

The following model is consistent with the modified Solow Growth Model and Two-Gap theory, as well as Eberhardt and Presbitero (2015) studies, thus, for the empirical analysis of the relationship among GDP, EXDBT, and CORR the model is specified as follows:

$$
\boldsymbol{E C N G}=f(E X T D B T+E X P O R T+G C F+C O R U P+D E B T I N \ldots(3)
$$

Based on the ECN functions, the econometrical can be finally specified model as follows:

$$
E C N G_{i t}=\alpha_{0}+\alpha_{1} E X T D B T_{i t}+\alpha_{2} E X P O R T_{i t}+\alpha_{3} G C P_{i t}+\alpha_{4} C_{\text {ORUP }}+\alpha_{5} \text { DEBTIN }_{i t} \ldots
$$

$\alpha_{i}$ is the parameter representing the intercept and slope coefficients; cit is the stochastic term. The model examines the relationship between EXTDBT and GDP on one hand, and ECNG and CORUP on the other hand. This is to particularly measure how external debts affects the level of ECNG in ASEAN countries, and the extent and direction of the effect of corruption on the levels of productivity and output in the five countries.

\section{Data}

The current study used secondary sources of data and pooled both the time-series and the cross-sectional data for the purpose of this research. The data comprises of external debt stock (EXDBT), gross capital formation (GCF), gross domestic product (GDP), interest on external debt (DEBTIN), exports of goods and services (EXPRT), and corruption (CORR), for those ASEAN countries that are chosen for this research, during 19902015. For statistical analysis, the data for EXPRT, DEBTIN, GCF, and EXDBT are taken from the International Financial Statistics and Direction of Trade Statistics of IMF and from World Bank, whereas, the data for CORR is taken from the International Country Risk Guide (ICRG).

\section{Panel Cointegration Test}

The test of cointegration is next examined to determine the long-run relationship among the variables. There are many methods of testing the cointegration of the variables, such as Maddala and Wu (1999), and Pedroni (1999). This study employs the technique developed by Pedroni (1999), which allows for considerable heterogeneity and uses the residual estimates from the hypothesized longrun regression. The long-run relation is of the form:

$$
Y_{i t}=\alpha_{i}+\delta_{i t}+\sum_{m=1}^{M} \beta_{m i} X_{m i}, t+\varepsilon_{i t}
$$

where $t=1, \ldots, T ; i=1, \ldots, N$; and $m=1, \ldots, M$; $T$ represent total number of observations at a specified time, $M$ represents the total number of regressors involved in this study and $N$ shows number of cross-sections. Moreover, $\alpha$ i represents fixed effects parameters, which changes from one individual in cross-section data to the other; $\delta$ it represents the time trend, and the slope coefficient, involving time related effect. 
In Equation [5], Yit represents the dependent variable (GDPit) and Xmi,t represent the regressors (EXTDBTit, EXPRTit, GCFit, CORURit, DEBTINit). In order to cover both the within and between effects (bin Hidthiir et al., 2019; Basheer et al., 2018), Pedroni (1999) developed seven distinct cointegration statistics which were classified into two, based on the Phillips-Perron and ADF tests panel versions; thus applying them to residuals from panel estimation.

When there exist co-integration relation, this refers to the existence of long term association between the variables. However, it does not provide a detailed knowledge about the causality direction. For analyzing the casual relation in the short run and long run between the variables, a two step method has been adopted in this study, which was referred by Engle and Granger (1987). The causality direction has been examined through this test between the macroeconomic variables incorporated in the research model. The causality between two variables, which have close association, is investigated through this method. It is tested in the null hypothesis that the variable $\mathrm{X}$ do not cause any variation in the variable $\mathrm{Y}$. however, it can be interesting to analyze that if the variable CORR is caused by GDP or GDP is caused by CORR. In explanation the causal relation runs from $\mathrm{GDP} \rightarrow \mathrm{CORR}$ ) or CORR $\rightarrow$ GDP. It is supposed in this test that the time series of the variables include the related information for predicting CORR and GDP. Therefore, the estimation of the regression pair is entailed by Granger causality test.

$$
\begin{aligned}
& E C N G_{i t}=\sum_{t=1}^{n} \beta_{i} E X T D B T_{i t-1}+\sum_{t=1}^{n} \beta_{j} E C N G_{i t-1}+\varepsilon_{1 i t} \ldots \ldots \ldots(6) \\
& E_{X T D B T_{i t}}=\sum_{t=1}^{n} \beta_{i} E X T D B T_{i t-1}+\sum_{t=1}^{n} \beta_{j} E C N G_{i t-1}+\varepsilon_{2 i t} \ldots . .(7) \\
& E C N G_{i t}=\sum_{t=1}^{n} \beta_{i} \operatorname{CORUP}_{i t-1}+\sum_{t=1}^{n} \beta_{j} E C N G_{i t-1}+\varepsilon_{1 i t} \\
& \operatorname{CORUP}_{i t}=\sum_{t=1}^{n} \beta_{i} \operatorname{CORUP}_{i t-1}+\sum_{t=1}^{n} \beta_{j} E_{C N G_{i t-1}}+\varepsilon_{2 i t}
\end{aligned}
$$

The two-variable causality assumption is known as 'Bi-Directional Causality'.

\section{Results}

\begin{tabular}{|c|c|c|}
\hline Test & Constant & Constant+Trend \\
\hline Panel v-Statistics & -1.926 & -2.8731 \\
\hline Panel $\rho$-Statistics & 0.07231 & -8.7632 \\
\hline Panel $t$-Statistics (non-parametric) & $-6.6752^{* * *}$ & $-6.674^{* * * *}$ \\
\hline Panel $t$-Statistics (parametric) & $-4.327^{* * *}$ & 2.923 \\
\hline Group $\rho$-Statistics & 2.732 & $-10.253^{* * *}$ \\
\hline Group $t$-Statistics (non-parametric) & $-7.762 * * *$ & $-4.324 * * *$ \\
\hline Group $t$-Statistics (parametric) & $-3.877 * * *$ & \\
\hline
\end{tabular}

The null hypothesis is rejected at 5 percent significance level by the ADF, the panel and group $t$ statistics, even the conditions are constant or constant plus trend. Therefore, the null hypothesis rejection is supported by most of the statistics, which reflects that there exists a long term association between the variables with reference to the ASEAN countries. In the conditions of constant or constant plus trend, the parametric (ADF-statistics) and non-parametric (t-statistics) are considered reliable (Pedroni, 1999). In this regard, the Table 3 shows the results, which lead to the conclusion that there is a long term association between the variables. 


\begin{tabular}{|c|c|}
\hline Dependent Variable: $\boldsymbol{E} \boldsymbol{C} \boldsymbol{N G}$ & $\begin{array}{c}\text { Fixed Effect } \\
\text { Coefficient } \\
\text { (p-value) }\end{array}$ \\
\hline EXTDBT & $-0.0177^{* * *}$ \\
\hline EXPORT & $(0.010)$ \\
\hline & $0.0198^{* *}$ \\
\hline GCF & $(0.027)$ \\
\hline CORUP & $0.0254^{* *}$ \\
\hline & $(0.014)$ \\
\hline DEBTIN & $-0.1222^{* * *}$ \\
\hline & $(0.006)$ \\
\hline $\boldsymbol{R}^{\wedge} \mathbf{2}$ & $0.0797^{* *}$ \\
\hline & $(0.033)$ \\
\hline
\end{tabular}

FMOLS Regression Results

There is negative relation of EXDBT with the GDP and it is statistically significant at 5 percent. It is explained by the coefficient that the reduction in GDP is caused by USD .62 when there is increased in EXDBT by USD1. The result is consistent with the hypothesis of debt overhand. However, the ECNG and level of investment declines when there is continuous increase in the accumulation of debt. The researchers including Eberhardt and Presbitero (2015) and Senadza et al. (2017) have obtained similar results. These results can be applicable to the Asian countries, where the borrowings have not been used in the productive activities and mismanagement occurred. Resultantly, there is depletion in the existing productive capital for financing of debt obligations. This leads to the decrease in the ECNG and domestic level of investment. The threat of capital flight may increase by continuous debts. However, the probability of being charged by taxes can be anticipated by the investors to fulfill their debts obligations (Mejdoub, \& Arab 2017). The capital repatriation can be considered in short term until there are improvements in the economic conditions. When the situation becomes favorable, the output of the economy is reduced.

In the similar way, it is reflected by the coefficient of DEBTIN that it is significant at $5 \%$ level and shows a negative association between GDP and DEBTIN. The increase in interest by USD1 leads to decline of USD2.30 in GDP. The interest can be increased by high servicing cost or accumulation. The results are consistent with the study of Mohd Dauda, Ahmad, and Azman-Saini (2013) and Abdullahi et al. (2016). It is implied that similar effect can be created on ECNG by interest payments imposed on such debts being external. The actual repayment on the debts maturity is compounded by interest payments.

\begin{tabular}{|c|c|c|c|}
\hline \multicolumn{5}{|c|}{ Equation 6 } \\
\hline Excluded & Chi-sq & df & Prob. \\
\hline EXTDBT & 34.651 & 2 & 0.000 \\
\hline EXPORT & 20.219 & 2 & 0.000 \\
\hline GCF & 78.236 & 2 & 0.000 \\
\hline CORUP & 95.231 & 2 & 0.000 \\
\hline DEBTIN & 7.234 & 2 & 0.000 \\
\hline All & $\mathbf{2 3 5 . 5 7 1}$ & $\mathbf{1 0}$ & $\mathbf{0 . 0 0 0}$ \\
\hline \multicolumn{7}{|l|}{ Equation 7 } & 0.000 \\
\hline ECNF & 43.387 & 2 & 0.000 \\
\hline EXPORT & 12.543 & 2 & 0.000 \\
\hline GCF & 28.438 & 2 & 0.000 \\
\hline CORUP & 17.721 & 2 & 0.000 \\
\hline DEBTIN & 23.561 & $\mathbf{1 0}$ & $\mathbf{0 . 0 0 0}$ \\
\hline All & 125.651 & 2 & \\
\hline
\end{tabular}




\begin{tabular}{|c|c|c|c|}
\hline \multicolumn{5}{|c|}{ Equation 8 } \\
\hline ECNF & 3.235 & 2 & 0.000 \\
\hline EXPORT & 21.143 & 2 & 0.000 \\
\hline GCF & 8.276 & 2 & 0.000 \\
\hline CORUP & 5.811 & 2 & 0.000 \\
\hline EXTDBT & 7.871 & 2 & 0.000 \\
\hline All & $\mathbf{4 6 . 3 3 6}$ & $\mathbf{1 0}$ & $\mathbf{0 . 0 0 0}$ \\
\hline \multicolumn{7}{|c|}{ Equation 9 } & 0.000 \\
\hline ECNF & 8.281 & 2 & 0.000 \\
\hline EXPORT & 4.376 & 2 & 0.000 \\
\hline GCF & 4.438 & 2 & 0.000 \\
\hline DEBTIN & 21.828 & 2 & 0.000 \\
\hline EXTDBT & 3.761 & $\mathbf{1 0}$ & $\mathbf{0 . 0 0 0}$ \\
\hline All & $\mathbf{4 2 . 6 8 4}$ & & \\
\hline
\end{tabular}

Table 3 represents the results of causality direction between the variables of interest examined through granger causality test. It is explained by the results that the causality runs from GDP through EXTDBT. The causality runs from EXDBT through GDP. This indicates a bi-directional relation of causality between the two variables. In each case, the value of probability is less than 5 percent. In the similar way, there is bi-directional causality relation between DEBTIN and EXDBT. Uni-directional causality exists between CORR and DEBTIN, and DEBTIN and GDP. However, there is no evidence for direction of causality running from GDP to CORR. It shows that the variables CORR and GDP are independent of each other.

\section{Conclusion}

The findings of the study show that the relationship between external debt and ECNG is negative, thereby confirming the debt overhang theory of external debt. This theory upholds that a sustained increase in government borrowing has tendency to reduce investment and ECNG, in the event that investors are made to pay higher taxes in order to allow the servicing of government debt. Similarly, the interest on external debt is also found to be negatively related to ECNG, thereby implying the existence of negative relationship between the stock of external debt and ECNG. In the same way, while most of the studies obtained that corruption reduces the level of economic productivity, the finding of this study supports few theoretical and empirical studies, who uphold that corruption enhances economic productivity and growth. This suggests that some forms of corruption are required to avoid bureaucracy especially in public service, where 'what belongs to all is seen to belong none'. Finally, the results of the panel granger causality show the evidence of bi-directional causality between ECNG and external debt, while no evidence of causality is found between corruption and ECNG. Considering the negative results on the economy, there is need for addressing the threat of increasing debt by the government through using alternative sources of capital investment. This can include economy openness for capital and relaxing the import restrictions and increased valuable exports. Investment can be increased in the domestic economy and wealth can be created through realizing the in tax revenue from capital imported, which is against the interest payment on external debt. Moreover, the investment can increase ECNG, which results in transfer of technology to the domestic economy increasing the probability of more employment opportunities.

In the similar way, the increase in corruption level among the ASEAN economies must be resolved. Inducements have been seen by the public services before the statutory performance as custom, which shows an uncontrollable corruption level. This causes severe influence on output as well. There is need for suitable policy in this aspect based on sincerity, integrity and severe penalties should be imposed on corruption act. Independent and credible actions should be conducted by different government agencies of anti-corruption. When illegal rewards and less penalty is involved in corruption, this attracts more corruption. The adverse influences of corruption must be expended with proper orientation to the new generations. In this way, they can be realized about corruption free acts in life. 


\section{References}

Abdullahi, M. M., Hassan, S. B., \& Bakar, N. A. B. A. (2016). Analyzing the impact of external debt on capital formation in Nigeria: an autoregressive distributed lag approach. Mediterranean Journal of Social Sciences, 7(1), 173. https://mpra.ub.uni-muenchen.de/id/ eprint/72086

Baltgailis, J. 2019. The issues of increasing the effectiveness of teaching comparative economics. Insights into Regional Development, 1(3), 190-199. https://doi.org/10.9770/ird.2019.1.3(1)

Bardhan, P. (2018). Reflections on Corruption in the Context of Political and Economic Liberalization Institutions, Governance and the Control of Corruption (pp. 113-131): Springer.

Basheer, M. F., Khan, S., Hassan, S. G., \& Shah, M. H. (2018). The Corporate Governance and Interdependence of Investment and Financing Decisions of Non-Financial Firms in Pakistan. The Journal of Social Sciences Research, 316-323.

bin Hidthiir, M. H., Basheer, M. F., \& Hassan, S. G.(2019) The Simultaneity of Corporate Financial Decisions Under Different Levels of Managerial Ownership: A Case of Pakistani Listed Firms.

Bruno, M., \& Chenery, H. B. (1962). Development alternatives in an open economy. Economic Journal, 72(285), 79-103.

Buthelezi, E. M., \& Nyatanga, P. (2018). Government debt and economic growth: evidence from ECOWAS and SADC. African Journal of Business and Economic Research, 13(3), 7-25. http://doi.org/10.31920/1750-4562/2018/v13n3a1

Chitra, V. and S.V. Anu, 2018. A community model of mental health promotion - its relevance in education - the story of MEHAC in India. International Journal of Innovation, Creativity and Change, 4(3): 117-124.

Chiu, Y. B., \& Lee, C. C. (2017). On the impact of public debt on economic growth: does country risk matter? Contemporary Economic Policy, 35(4), 751-766. https://doi.org/10.1111/coep.12228

Çiftçioğlu, S., \& Sokhanvar, A. (2018). External Debt-Economic Growth Nexus in Selected CEE Countries. Romanian Journal of Economic Forecasting, 21(4), 85.

Coupet Jr, E. (2003). Corruption, investment and economic growth: theory and international evidence. Journal of Business \& Economics Research (JBER), 1(1).

Coupet, E. (2018). Public Debt, Capital Accumulation, and Economic Growth: Is there a Nonlinear Relationship? Journal of Applied Economics \& Business Research, 8(3). http://www.aebrjournal.org/uploads/6/6/2/2/6622240/joaebrseptember2018_140_161.pdf

David, L., F. Paul, S. Ken, T. David and Y. Tony, 2018. Towards an effective model for whole of school blended learning: A conceptual paper. International Journal of Innovation, Creativity and Change, 4(1): 29-51.

Domar, E. D. (1946). Capital expansion, rate of growth, and employment. Econometrica, Journal of the Econometric Society, $137-147$.

Eberhardt, M., \& Presbitero, A. F. (2015). Public debt and growth: Heterogeneity and non-linearity. Journal of international Economics, 97(1), 45-58. http://doi.org/10.1016/j.jinteco.2015.04.005

Engle, R. F., \& Granger, C. W. (1987). Co-integration and error correction: representation, estimation, and testing. Econometrica: journal of the Econometric Society, 251-276.

Gründler, K., \& Potrafke, N. (2019). Corruption and economic growth: New empirical evidence. European Journal of Political Economy.

Harrod, R. F. (1939). An essay in dynamic theory. The economic journal, 49(193), 14-33. https://www.ifo.de/DocDL/wp-2019-309-gruendler-potrafke-corruption-growth.pdf

Haseeb, M., Kot, S., Hussain, H., \& Jermsittiparsert, K. (2019). Impact of Economic Growth, Environmental Pollution, and Energy Consumption on Health Expenditure and R and D Expenditure of ASEAN Countries. Energies 12(19), 3598.

Huang, C.-J. (2016). Is corruption bad for economic growth? Evidence from Asia-Pacific countries. The North American Journal of Economics and Finance, 35, 247-256. http://doi.org/10.1016/j.najef.2015.10.013

Ivanyna, M., Moumouras, A., \& Rangazas, P. (2016). The culture of corruption, tax evasion, and economic growth. Economic Inquiry, $54(1), 520-542$.

Jermsittiparsert, K, Sriyakul, T., \& Pamornmast, C. (2012). The "Populism” Policy and Building/Diminishing Economic "Inequality" 
and "Unfairness": Empirical Suggestion on Pork-Barrel in Thailand's Rice Trading Business. Public Policy and Administration Research, 2(7), 21-31.

Jermsittiparsert, K, Sriyakul, T., \& Rodoonsong, S. (2013). Power(lessness) of the State in the Globalization Era: Empirical Proposals on Determination of Domestic Paddy Price in Thailand. Asian Social Science, 9(17), 218-225. http://doi.org/10.5539/ass.v9n17p209

Kaplan, E. A., \& Akçoraoğlu, A. (2017). Political Instability, Corruption, and Economic Growth: Evidence from a Panel of OECD Countries. Business and Economics Research Journal, 8(3), 363.

Kasayanond, A., Umam, R., \& Jermsittiparsert, K. (2019). Environmental Sustainability and its Growth in Malaysia by Elaborating the Green Economy and Environmental Efficiency. International Journal of Energy Economics and Policy, 9(5), 465-473. http://doi. org/10.32479/ijeep. 8310

Kaur, K. (2019). Causality between public debt, exports and economic growth in India. Asian Journal of Multidimensional Research (AJMR), 8(4), 142-155.

Keynes, J. M. (1929). The German transfer problem. The economic journal, 39(153), 1-7.

Khan, I. (2018). The Impact of Land Use on Spatial Variations of Begging in District Lahore_Pakistan. International Journal of Geography and Geology, 7(2), 27-34. http://doi.org/10.18488/journal.10.2018.72.27.34

Korkmaz, S. (2015). The relationship between external debt and economic growth in Turkey. Paper presented at the Proceedings of the Second European Academic Research Conference on Global Business, Economics, Finance and Banking, Zurich-Switzerland.

Lambsdorff, J. (2015). Behavioural and institutional economics as an inspiration to anti-corruption. Some counter intuitive findings. Routledge Handbook of Political Corruption, 299-314.

Lari, L. R. A., NYangweso, P. M., \& Rono, L. J. (2017). Determinants of Technical Inefficiency of Saccos in Kenya: A Net Operating Cash Flows Output Slack Analysis. Asian Journal of Economics and Empirical Research, 4(2), 49-60.

Lazreg, M., \& Mohammed, K. S. (2019). Corruption and Democracy in Middle East and North Africa Countries: Dynamic Generalized Method of Moments. International Journal of Economics and Financial Issues, 9(1), 60.

Loukil, K. (2017). Technological Innovation in Central and Eastern Europe: What's the Contribution of Innovation Policy?. The Economics and Finance Letters, 4(1), 1-8.

Luzgina, A. (2017). Problems of corruption and tax evasion in construction sector in Belarus. Entrepreneurship and Sustainability Issues, 5(2), 263-282. http://doi.org/10.9770/jesi.2017.5.2(8)

Mabika, H. (2016). The Human Capital Retention Strategies that Local Authorities in Zimbabwe Can Adopt for Successful Talent Retention. International Journal of Management and Sustainability, 5(3), 17-22.

Maddala, G. S., \& Wu, S. (1999). A comparative study of unit root tests with panel data and a new simple test. Oxford Bulletin of Economics and statistics, 61(S1), 631-652.

Mahmud, U. E. (2018). External Debt Burden and Management in the Third World: a Cross-Country Analysis of Nigeria and Indonesia. Social Sciences, 5(1).

Malik, K., \& Khan, F. N. (2013). Narcissistic Leadership at Workplace and the Degree of Employee Psychological Contract: A Comparison of Public and Private Sector Organizations in Pakistan. International Journal of Economics Business and Management Studies, 2(3), 116-127.

Manaf, N. A., \& Ibrahim, K. (2017). Poverty reduction for sustainable development: Malaysia's evidence-based solutions. Global Journal of Social Sciences Studies, 3(1), 29-42.

Marshal, I. (2017). Product Brand and Customer Loyalty: A Survey of the Nigeria Banking Industry. Journal of Accounting, Business and Finance Research, 1(1), 7-18.

Mbaku, J. M. (2019). Corruption and Economic Development污 African economic development (pp. 331-345): Emerald Publishing Limited.

Megersa, K. A. (2015). The laffer curve and the debt-growth link in low-income Sub-Saharan African economies. Journal of Economic Studies, 42(5), 878-892.

Mejdoub, H., \& Arab, M. B. (2017). A multivariate analysis for risk capital estimation in insurance industry: Vine Copulas. Asian De- 
velopment Policy Review, 5(2), 100-119.

Mikail, A., \& Zainol, Z. A. (2018). Conservation of Biodiversity in Sub Sahara Africa: Prospecting for Genetic Resources and Traditional Knowledge Regulation in Ethiopia. International Journal of Asian Social Science, 8(9), 725-734.

Mohd Dauda, S. N., Ahmad, A. H., \& Azman-Saini, W. (2013). Does external debt contribute to Malaysia economic growth? Economic research-Ekonomska istraživanja, 26(2), 51-68.

Mustafa, M. E., Elshakh, M. M., \& Mustafa, M. E. (2018). Does Foreign Aid Promote Economic Growth in Sudan? Evidence from ARDL Bounds Testing Analysis. Paper presented at the Economic Research Forum's(ERF) 24th Annual Conference. Retrieved from http://www.erf.org.eg/wp-content/uploads/2018/02/4-23-Mahjoub-Ebaidallah.Pdf

Olawale, \& Hassan, S. (2016). The size of government and external debt: a panel analysis of five SSA countries. International Journal of Economic Perspectives, 10(4), 685-694.

Olawale, S. W. (2017). External debt, corruption, and economic growth in selected five Sub-Saharan African countries. Universiti Utara Malaysia.

Osipov, G.V., Glotov, V.I., Karepova, S.G. (2018). Population in the shadow market: petty corruption and unpaid taxes. Entrepreneurship and Sustainability Issues, 6(2), 692-710. http://doi.org/10.9770/jesi.2018.6.2(16)

Pedroni, P. (1999). Critical values for cointegration tests in heterogeneous panels with multiple regressors. Oxford Bulletin of Economics and statistics, 61(S1), 653-670. https://doi.org/10.1111/1468-0084.0610s1653

Popov, A. (2018). Evidence on finance and economic growth Handbook of Finance and Development: Edward Elgar Publishing.

Prakash, R., Garg, P. (2019). Comparative assessment of HDI with Composite Development Index (CDI). Insights into Regional Development, 1(1), 58-76. https://doi.org/10.9770/ird.2019.1.1(5)

Senadza, B., Fiagbe, K., \& Quartey, P. (2017). The effect of external debt on Economic Growth in Sub-Saharan Africa. International Journal of Business and Economic Sciences Applied Research (IJBESAR), 11(1).

Siddique, A., Selvanathan, E., \& Selvanathan, S. (2015). The impact of external debt on economic growth: Empirical evidence from highly indebted poor countries: University of Western Australia, Economics.

Stone, K. (2019). Debt Accumulation and Economic Growth in Emerging Market Economies: Is Debt Promoting or Hindering Growth? https://digitalcommons.wku.edu/cgi/viewcontent.cgi?article=1821\&context=stu_hon_theses

Strout, R. B. (1966). Portable tube end cutting tool: Google Patents.

Tanzi, V., \& Davoodi, H. (1998). Corruption, public investment, and growth The welfare state, public investment, and growth (pp. 41-60): Springer. https://www.imf.org/external/pubs/ft/wp/wp97139.pdf

Todaro, M. P., \& Smith, S. C. (2004). Pembangunan Ekonomi di Dunia Ketiga Edisi Kedelapan. Jakarta: Penerbit Erlangga.

Whajah, J., Bokpin, G. A., \& Kuttu, S. (2019). Government size, public debt and inclusive growth in Africa. Research in International Business and Finance, 49, 225-240. https://doi.org/10.1016/j.ribaf.2019.03.008

Zeibote, Z., Volkova, T., Todorov, K. (2019. The impact of globalization on regional development and competitiveness: cases of selected regions. Insights into Regional Development, 1(1), 33-47. https://doi.org/10.9770/ird.2019.1.1(3) 
Sakapas SAENGCHAI is studying Ph.D. in Public Administration at Ramkhamhaeng University Thailand. He currently is Assistant Professor in Public Administration at the Faculty of Humanities and Social Sciences, Suan Sunandha Rajabhat University. His areas of expertise are Public and Private Administration and Interdisciplinary Studies in Social Sciences.

Chanathat BOONRATTANAKITTIBHUMI holds Ph.D. in Management from Siam University Thailand. He currently is a lecturer at King Moungkult's Institute of Technology, Prince of Chumphon Campus, Thailand. His research areas are in Management, Strategy Management, Social Enterprise, Organizations, Business Model, Agribusinesses, and Tourism.

Buppachat URAIRAK holds PhD in Management from Siam University, Thailand. She is currently an instructor of MBA Program in Industrial Management at Ramkhamhaeng University, Thailand and a part-time lecturer at Police Nursing College, Tailand. Her areas of expertise are Business Administration, Supply Chain Management, and Healthcare.

Register for an ORCID ID:

https://orcid.org/register

This work is licensed under the Creative Commons Attribution International License (CC BY).

http://creativecommons.org/licenses/by/4.0/ 